Magdalena Popiel

\title{
Cóż po doświadczeniu wojny w czasie zarazy? Kilka uwag o definiowaniu kultury
}

\begin{abstract}
Popiel Magdalena, Cóż po doświadczeniu wojny w czasie zarazy? Kilka uwag o definiowaniu kultury [The meaning of war experience in pandemic times. A few notes on defining the concept of culture]. „Przestrzenie Teorii” 34. Poznań 2020, Adam Mickiewicz University Press, pp. 117-145. ISSN 1644-6763. DOI 10.14746/pt.2020.34.5.

The paper reflects on the concept of culture from the perspective of those who've experienced the cataclysms of the 20th and 21st centuries. The author poses questions about the current experience of the pandemic to verify the "usefulness" of the dominant cultural patterns. The author analyses the particular war experiences of Czesław Miłosz in Warsaw (Legends of Modernity) and Józef Czapski in a prisoner-of-war camp (Proust in Griazowiec). At the center of their traumatic experience is the process of seeking salvation through cultural gestures. The experience of war reveals both the strength and weakness of the fundamental version of culture. The article ends with a question about the topicality of this experience and the upholding power of modern culture.
\end{abstract}

KEYWORDS: culture, experience, war, pandemic, literature, Czesław Miłosz, Józef Czapski

Pojawiające się często w publicystyce porównywanie czasu pandemii do wojny dla jednych jest czymś oczywistym, używanym chociażby po to, by uruchomić wyobraźnię skali tragedii (,w Nowym Jorku zmarło więcej ludzi niż w czasie ataku na World Trade Center”, „zmarło więcej niż w czasie całej wojny w Wietnamie...”), dla innych zaś czymś niestosownym. Piszę to zdanie w momencie, gdy licznik zmarłych na koronawirusa w świecie pokazał 554 249. Wojna, przemoc zbiorowa jako domena okrucieństwa człowieka, tak jak kataklizmy i zarazy - okrucieństwo natury staje się dojmującym doświadczeniem wspólnotowym i jednostkowym XXI wieku ${ }^{1}$. Do jakiego stopnia czas pandemii pozostanie stanem wyjątkowym, a do jakiego właczy nas w powtarzalny rytm doświadczeń cywilizacyjnych - to zagadnienie, które pojawia się już na horyzoncie.

Cóż zatem począć z doświadczeniem 2020 roku? Będąc w centrum przeżycia, które szokuje nowością zarówno w perspektywie indywidualnej egzystencji, jak i w skali doświadczenia globalnego, jesteśmy ciagle na etapie

${ }^{1}$ Zestawienie doświadczenia zarazy z doświadczeniem wojny może być motywowane przypisaniem im jakości „dużego” doświadczenia, które z wieloma zastrzeżeniami próbował wprowadzić Roger-Pol Droit. Definiował on duże doświadczenie jako „podnoszące naszą zdolność działania”; doświadczenie jest znaczące, ,jeśli zwiększa nasze możliwości udziału w życiu, nasze zdolności percepcji, rozumienia czy też pragnienia” (Wielkie doświadczenie, przeł. R. Ryziński, „Teksty Drugie” 2006, z. 3, s. 108). 
poszukiwania naukowych diagnoz i odpowiedzi na piętrzące się pytania. Niezależnie od wiedzy medycznej, historycznej, socjologicznej i psychologicznej, która będzie zapewne stopniowo zaspokajać nasze ambicje poznawcze, można już dziś, szukając pewnych analogii, próbować formułować pytania. Podejmowana dziś refleksja oznacza de facto przyjęcie perspektywy aktualnego i ciagle żywego doświadczenia zakładającego zaangażowanie w trwającą nadal rzeczywistość pandemii.

Używam pojęcia doświadczenia w jego podstawowym znaczeniu utrwalonym w polskiej tradycji jako bycia poddawanym próbie ${ }^{2}$. Kariera tej kategorii w humanistyce w ciagu ostatnich dekad wyrosła z przekonania, że doświadczenie jest źródłem i fundamentem wszelkich pojęć i idei, zyskała mocną legitymizację zarówno w koncepcji kryzysu doświadczenia, jak i we wspólnotowych, niekiedy globalnych doznaniach. Problematyka łączona często z pojęciem nowoczesności wchłaniała rozległy obszar relacji podmiotu ze światem na przestrzeni ostatnich stuleci ${ }^{3}$.

Współczesne doświadczenie pandemii ma wiele komponentów, traumę rodziło przeżycie izolacji i choroby, wyzwaniem stała się zmiana relacji interpersonalnych w waskim kręgu osób. Komunikacja społeczna obarczona została licznymi restrykcjami, ale sprzyjała też inwencyjności. Poczucie strachu prowokowało agresję, ale równie często szukało ujścia w niezwykłej empatii. Zanim doczekamy się po pandemii tak radykalnego rozliczenia z przeszłościa, jakie przygotowali Max Horkheimer i Theodor W. Adorno, pisząc w czasie wojny i publikując w 1947 roku Dialektykę oświecenia, a zatem może Dialektykę ponowoczesności dokonująca przewartościowania mitów XX i XXI wieku, pozostają nam wattki poboczne, lokalne i „przypadkowe”, które warto już dziś podejmować. Stwarzają one często dogodny punkt obserwacji szerszego horyzontu kultury.

Przez pierwsze miesiące pandemii 2020 roku stawały mi przed oczami dwa obrazy z czasu drugiej wojny światowej, wyobrażenia zrodzone z lektury. Jeden to obraz Czesława Miłosza w wojennej Warszawie piszącego eseje, listy, wiersze; drugi - to portret Józefa Czapskiego przebywającego w tym samym mniej więcej czasie w obozie jenieckim w Griazowcu; opowiadał tam współwięźniom w ramach nauki języka francuskiego $W$ poszukiwaniu stra-

${ }^{2}$ Konotacje i pola semantyczne „doświadczenia” w polszczyźnie, nawiązując do ujęcia Barbary Skargi i Józefa Tischnera, omawiał m.in. R. Nycz (Trzy głosy o nowoczesności, doświadczeniu i literaturze, [w:] tegoż, Poetyka doświadczenia. Teoria-nowoczesność - literatura, Warszawa 2012).

${ }^{3} \mathrm{Na}$ polskim gruncie szczególnie inspirujące były badania nad doświadczeniem nowoczesności z perspektywy kulturowo-antropologicznej prowadzone przez Ryszarda Nycza i Annę Zeidler-Janiszewska, począwszy od konferencji „Nowoczesność jako doświadczenie” (Kraków 2006) i tomu pokonferencyjnego oraz numeru „Tekstów Drugich” - Doświadczenie: reaktywacja (2006, nr 3). 
conego czasu Marcela Prousta i zapełniał każdy skrawek papieru notatkami i rysunkami. Dwa epizody w dwóch biografiach rozciagniętych prawie na całe stulecie XX wieku. Epizody, które jednak trwały dłużej niż sekwencja naszych aktualnych doświadczeń.

Głosy Miłosza i Czapskiego dobiegają z samego środka wydarzeń wojennych. Zarazem jednak partykularna sytuacja życiowa, w jakiej się znaleźli, stwarza szczególny rodzaj dystansu wobec toczącej się wojny. Choć warunki egzystencjalne Miłosza zamkniętego w swoim warszawskim mieszkaniu i Czapskiego zesłanego wraz z innymi jeńcami do obozu sowieckiego sa diametralnie różne, to jednak poczucie izolacji, lęk przed rozlewającym się wokół okrucieństwem połączony z potrzebą diagnozującej, wielowątkowej refleksji, znacząco zbliża ich do siebie. Czy zbliża ich także do naszej sytuacji, czy ich odpowiedź na rzeczywistość, w jakiej się znaleźli, jest zasadniczo inna kulturowo i może być rozpatrywana jedynie jako casus historyczny?

\section{Cywilizacja jak "olbrzymi ser". O dziwnej sytości w czasie głodu}

Ze wspomnień Miłosza i Czapskiego z 1941 i 1942 roku przypomnę dwa zdarzenia nadające ich wyimaginowanym portretom szczególny rys.

Życie Miłosza w wojennej Warszawie koncentrowało się w kilku miejscach: jednym z nich była kamienica przy alei Niepodległości 131, gdzie wraz z Janką Dłuską i jej rodzicami zajmowali mieszkanie na pierwszym piętrze, innym - Biblioteka Uniwersytetu Warszawskiego, w której Miłosz znalazł wówczas pracę. Po okresie dramatycznego przemierzania polskich szlaków ewakuacji na przełomie 1939 i 1940 roku, egzystencja Miłosza na cztery lata zamknęła się w przestrzeni tego miasta. Mury mieszkania, kamienicy, BUW-u wyznaczały w życiu pisarza granice pewnej enklawy. Tom wojennych esejów opublikowany pod tytułem Legendy nowoczesności rozpoczyna się od tekstu Legenda wyspy: wojna stała się czasem przeorganizowania przestrzeni, wyznaczenia jej nowych granic, konstytuowania od początku tego, co wewnętrzne i zewnętrzne. Tę Miłoszową wyspę rychło porosła dziwna, niesamowicie bujna... „niebieskozielona dżungla dzieł lite-

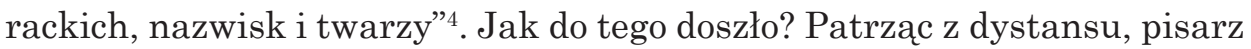
podkreśli rolę przypadku, który miał zadecydować o jego ówczesnej sytuacji życiowej, mentalnej i twórczej:

${ }^{4}$ List do Jana Błońskiego z 3 kwietnia 1963 roku, [w:] J. Błoński, Cz. Miłosz, Listy 1958-1997, zebrał, przepisał i opatrzył przypisami A. Puchejda, Gdańsk 2019, s. 55. 
Dlaczego napisałem wtedy tę książkę? Z powodu bomby niemieckiej, która we wrześniu 1939 roku trafiła w to skrzydło Pałacu Staszica, gdzie mieścił się Instytut Francuski. Jego bogaty księgozbiór leżał w stosach zmieszany z gruzem. Powoli oczyszczało się tomy z pyłu i przewoziło się do Biblioteki Uniwersyteckiej. Przez pewien czas byłem przy tym zatrudniony, prawdę rzec za zupkę, bo dniówka wynosiła grosze. I właśnie te francuskie tomy odkładane na bok, jeżeli zafrapował mnie autor czy tytuł, dostarczyły pierwszego impulsu ${ }^{5}$.

Ta anegdota przekazana reporterskim stylem we wstępie do Prywatnych obowiazków ma swój dalszy ciąg w pisanych wówczas artykułach i listach, które obfitują w intrygująca metaforykę. Fragmenty korespondencji z Janem Błońskim czy te pochodzace z Rodzinnej Europy umieszczaja „dżunglę” zarówno po stronie opisu miasta „z jego falami popłochu i wybuchająca tu i ówdzie strzelanina”, , jak i po stronie „puszczy” literatury, „która dawała schronienie od pokoleń i była prawdziwsza niż jakikolwiek świat"7. Dżungla wojny mówiła o dzikości i okrucieństwie, dżungla kultury wabiła bogactwem, przygoda, a także poczuciem bezpieczeństwa, autentycznością i prawda. Nieprzewidywalność i dominująca reguła przypadku były w tych dwóch światach odmiennie wartościowane. Metaforyka prozy wojennej Miłosza zaskakuje intensywnością zmysłowych przenośni: o lęku i strachu mówi poprzez obraz bezbronnego w swojej nagości ciała („Niestety były to czasy, kiedy narzucano wszystkim elementarny strach o życie i wtedy każdy musiał poruszać się nago, niby owad wyjęty spod kory i rzucony o płytę" $)$, o książkach opowiada jako o obiekcie pragnień człowieka zagłodzonego. Później, wspominając te czasy, Miłosz napisze w liście do Błońskiego: „kontrast biblioteki uniwersyteckiej, gdzie przyczepiłem się jako tragarz, na marchwianych zupkach, z ulica - chyba naprawdę po raz pierwszy poczułem ludzkość czy cywilizację jako olbrzymi ser, ja w tym serze, cóż za uczta - i odtąd tak ze mną stale"9.

Odczucie wyjątkowej sytości w podobnej sytuacji głodu ciała przeżywał Józef Czapski podczas pobytu w obozie w Griazowcu:

Griazowiec miał szczupła, ale cenna, rozrywaną przez nas - jeńców, bibliotekę: byli tam klasycy rosyjscy, między innymi parę tomów wielkiego wydania Tołstoja, był tam tom brulionów do Anny Kareniny, które nie weszły do wersji ostatecznej, byli Francuzi XIX wieku, dużo Balzaców (na szczęście Marks kochał Komedię ludzka),

${ }^{5}$ Cz. Miłosz, Legendy nowoczesności, Kraków 2009, s. 309 (w kolejnych cytatach strony $\mathrm{w}$ nawiasach według tego wydania).

${ }^{6}$ Cz. Miłosz, Rodzinna Europa, Kraków 1994, s. 232.

${ }^{7}$ Cz. Miłosz, list do Jana Błońskiego z 3 kwietnia 1963 roku, [w:] J. Błoński, Cz. Miłosz, dz. cyt.

8 Tamże.

${ }^{9}$ Tamże, s. 58. 
Education sentimental Flauberta z doskonałym wstępem naświetlajacym epokę i z koniecznym chapeau marksistowskim, był nawet Thomas Hardy. Nigdy chyba tak uważnie nie czytałem [...] te doznania literackie, których byłem tak głodny, przeżywałem nieraz - stwierdziłem to wówczas ze wstydem jakby silniej niż runięcie Paryża czy bombardowanie Londynu. [...] Książki pomagały mi w budzeniu pamięci mimowolnej. Przypomniałem sobie, mając do tylu rzeczy fatalną pamięć, teksty, fragmenty innych książek, których wiele lat w ręku nie miałem, obrazy przeróżne widziałem oczami wyobraźni. Dla mnie samego to wypływanie wspomnień, jakby dawno zagubionych, graniczyło z cudem. Nie tylko ratowaliśmy się przed rozpacza, ale w tym drugim roku niewoli stwarzał się jakiś nawet podejrzany komfort: dotkliwość, brutalność grozy świata - gdzie człowiek musiał walczyć i ani chwili nie mógł być bierny, ani czysty, jeżeli nie umierał - jakby pokrywała się mgła, reakcja słabła, człowiek zdobywał dystans i nawet rezygnacja stawała się nie tak już niemożliwa ${ }^{10}$.

Te dwie historie wojenne wskazują na źródło szczególnej metody organizowania od nowa świata, w chwili gdy nagle „wypadł z kolein”. Dla pary bohaterów wszystko zaczynało się od przypadkowego, chaotycznego księgozbioru, to on stawał się axis mundi. Biblioteka, nie ta stworzona z pieczołowicie kolekcjonowanych dzieł, ale biblioteka będąca wojenną ruina, stała się odkryciem i ocaleniem. Literatura w karykaturalnej i szczątkowej wersji zbioru, karmiła umysł i ducha, była instrumentem autoterapii, syciła głód wyobraźni, stymulowała prace pamięci i intelektu.

Chciałabym umieścić te dwa portrety w kontekście ogólniejszym, wykraczającym poza konkretny czas i miejsce ${ }^{11}$. Jak zamknąć w jednym obrazie dżungle barbarzyńskiego okrucieństwa i gąszcz cywilizacji, zamknąć te światy w ciasnej, izolowanej przestrzeni podobnej do warszawskiego

${ }^{10}$ J. Czapski, Patrzqc, wybór, przedmowa i posłowie J. Pollakówna, Kraków 2016, s. 95 (kolejne cytaty według tego wydania - P).

${ }^{11}$ Myślenie per analogiam i retoryka przypowieści łączyły Miłosza i Czapskiego i były pomocne w rozważaniu oraz artykułowaniu pytań istotnych; oto fragment listu Józefa Czapskiego do Miłosza: „Mechaniczność powrotów zbrodni, krzywdy, załamań Polski, jej małości i jej wielkości [...] i to trzeba nazwać Łaską? [...] Opowiem Ci historię, dawną; przed 39 rokiem ktoś mi opowiadał (przyjąłem to jak trochę bajkę, może trochę prawdziwa, ale spamiętałem), że po zdobyciu Rzymu przez barbarzyńców tłumy Rzymian uciekły do Afryki, gdzie żył św. Augustyn. Z żalem, goryczą pytały, dlaczego Bóg zsyła klęski Rzymowi, który wtedy już był chrześcijański. Św. Augustyn wezwał do siebie młodego zakonnika Orozjusza. - «Ja jestem już stary i nie mam już sił, ale ty napisz historię świata, ale tak, żeby ludzie wiedzieli, że klęski, katastrofy są w historii zawsze». [...] W Encyklopedii starej, ogromnej, która kupiłem w Rzymie podczas wojny, znajduję, że to wszystko tak było: że Orozjusz napisał tę księgę po śmierci św. Augustyna, której tematem jest dowieść, że klęski były (i będa) zawsze!" Komentarz do tej historii, jaką Czapski w 1983 roku przesyła Miłoszowi, brzmi: „Ratunek Opatrzności? Światło to znaleźć możemy na dnie opuszczenia i nieszczęścia. Jaka opatrzność może uratować nasz świat, który tonie i który prawdopodobnie na nowo z nowymi nadziejami się odrodzi gdziekolwiek indziej” (List Józefa Czapskiego, 4 III 1983, [w:] Cz. Miłosz, Metafizyczna pauza, Kraków 1995, s. 213). 
mieszkania, jenieckiego obozu czy samotnej wyspy na wzburzonym oceanie? W poszukiwaniu tego szczególnego toposu pomocny będzie Zbigniew Herbert.

\section{Intertekst o świętym Hieronimie}

Rama interpretacyjna, którą chcę zaproponować, wyłania się z ekfrastycznego wiersza Zbigniewa Herberta napisanego w latach pięćdziesiątych. Liryk Colantonio - S. Gierolamo e il Leone opisujacy obraz Nicola Antonia Colantonia przedstawia św. Hieronima wraz z nieodłącznym atrybutem, czyli lwem ${ }^{12}$. Mało znany utwór przetłumaczony na niemiecki i opublikowany w roku 1967 w tomie Inschrift został kilkanaście lat po napisaniu zadedykowany Karlowi Dedeciusowi ${ }^{13}$. Geneza wiersza jest znana: w liście do Jerzego Zawieyskiego Herbert wspomina: „przypomniałem sobie, że w Neapolu widziałem obraz malarza Colantonio (II połowa XV wieku), który się nazywa Św. Hieronim i lew. To bardzo piękny obraz, a ponieważ nie byłeś ze mna, to ja pomyślałem, żeby Ci go - jak potrafię - opisać”. Początek wiersza brzmi tak:

Prawdę rzekłszy bałagan

książki w nieładzie

Organon Marx Engels Lolita Tractatus Logico Philosophicus

święty czyta wszystko

i na marginesie

mak komentarzy

porównaj strona 7 słusznie nie wnika

na biurku zwój pergaminów

pióro kałamarz klepsydra

bezużyteczne flaszeczki które pomagają w skupieniu

odbija się w nich świat odwrócony a więc podany w wątpliwość

Z liryku Herberta i obrazu neapolitańskiego malarza quattrocenta chcę wyjąć kilka zaledwie cegiełek. Potrzebne są do tego przede wszystkim „książki w nieładzie”, „świat odwrócony” oraz para bohaterów: ten „co czyta wszystko" i lew. Niech wyobrażenie Herberta nasycone wspomnieniem oglądanego w Neapolu malowidła stworzy dla nas pespektywę w renesansowym rozumieniu samej idei jako „widzenia poprzez”. Perspectiva artificialis niech oznacza sztuczny konstrukt okna, ramy, poprzez którą spojrzymy na przeszłość nieco dalszą niż moment powstania utworu, czyli czas wojny.

${ }^{12}$ Por. W. Kudyba, Święty Hieronim i Pan Cogito, <https://herbertguru.wordpress. com/2014/10/20/wojciech-kudyba-swiety-hieronim-pan-cogito/> [dostęp: 10.01.2021].

${ }^{13}$ Por. P. Choynowski, Herbert i jego tłumacz, „Postscriptum Polonistyczne” 2012, nr 1. 
Ikonografia św. Hieronima eksponuje dwa elementy, które wiążą się z legendą świętego, ale które też łatwo zmieniają się w przedmioty emblematyczne - to księga i lew. Hieronim przedstawiany zazwyczaj w swojej pracowni pochyla się nad tłumaczoną właśnie Biblia, jest uczonym otaczającym się pismami. Lew, jak głosi legenda, pojawił się w jego życiu nagle, siejąc popłoch i panikę wśród zakonników. Hieronim dostrzegł w jego łapie kolec, który skwapliwie usuną; wdzięczne zwierzę towarzyszyło od tej pory pracy świętego. Herberta skusił ten obraz do znakowej transpozycji i przeniesienia go w uniwersalny „czas odwrócony”. Proponuję pójść za tym impulsem i wpisać w tak skomponowane ramy wojenny portret Miłosza i Czapskiego ${ }^{14}$. W renesansowym obrazie dwa atrybuty - lew i księga komponuja się harmonijnie: lew przypomina leniwego kota a księgi zazwyczaj poukładane są w idealnym porządku na półkach pracowni, to świat-ogród, jak powiedziałby Miłosz, utopijna kraina, w której człowiek bezpiecznie i szczęśliwie przechadza się wśród przyjaznej Natury. Herbert swą wyobraźnią cofa czas do momentu, gdy piasek w klepsydrze jeszcze się nie przesypał: tu panuje bałagan, świat trochę na opak i jakże niepewny, niezrozumiały, rozproszony (z przykładnej egzegezy zrobił się „mak komentarzy”). W wyobrażonym portrecie Miłosza mityczny czas powinniśmy cofnać jeszcze bardziej, aż do momentu grozy wywołanej wtargnięciem zła, to znaczy chwili, gdy w ciasnym świecie eremity - Hieronima nagle pojawiło się to, co groźne, dzikie, obce. Św. Hieronim, patron bibliotekarzy i tłumaczy, staje przed wyzwaniem oswojenia zła - wyrywa mu kolec, neutralizuje oścień śmierci. Herbert zwrócił uwagę na znamienny szczegół, jakim jest instrument tej operacji: „długim łacińskim stylem święty wyciaga cierń z szarej opuszki”. Narzędziem oswojenia staje się warsztat pracy pisarza, Człowieka Księgi ${ }^{15}$, tego, który para się tłumaczeniem Księgi ksią.

Herbert nie wybiera na bohatera „świata odwróconego” świętego-żołnierza, który włócznią lub mieczem próbuje przeciwstawić się złu, nie przywołuje także świętego-męczennika cierpiącego z powodu okrucieństwa losu i ludzi. Rozszerzając kontekst wątku hagiograficznego, wskazuje możliwość spojrzenia na scenę z życia św. Hieronima jako rodzaj archetypicznego obrazu „człowieka księgi”, artysty i intelektualisty, w obliczu zła.

${ }^{14}$ Miłosz i Czapski spotkali się po raz pierwszy przypadkiem w Luwrze w 1935 roku, poeta dołączył na chwilę do grupy młodych malarzy kapistów, których oprowadzał po paryskim muzeum Pankiewicz. Może obaj zatrzymali się wtedy na chwilę przed obrazem Tycjana przedstawiającym św. Hieronima...

${ }^{15}$ „Ludzie Księgi” - to formuła Miłosza, która pojawia się m.in. w Zdaniach: „Ty, który myślisz o nas: żyli tylko złudzeniem,/ Wiedz, że nigdy nie zginie nasz ród, Ludzi Księgi” (Nagrobek), za: Cz. Miłosz, Wiersze wszystkie, Kraków 2018, s. 724. 


\section{Kultura i odkupienie}

Przeszłość jest ogromną księga z obrazkami, ale podmiot jej nie pokazuje się wyraźnie, rozchwiany, nieuchwytny, proteuszowo zmienny i przez to zawstydzajacy. Medytacja pociesza odważaniem strat i zysków, bo jednak nie tylko się traci: z upływem lat przybywa nam zmysłu architektonicznego i klarowności przęseł, linii jak w krysztale, wynagradza niedostatek ciepłych barw ${ }^{16}$.

W refleksji nad historią kultury uruchomienie zmysłu architektonicznego powoduje, że przęsła łączące „obrazki” księgi uwidaczniają się dla „medytującego” z całą wyrazistością. Świadomość estetycznej czy konstruktywistycznej natury historii nie była obca Miłoszowi ${ }^{17}$.

Czesław Miłosz czytajacy w Warszawie 1942 roku powieści francuskie, piszacy eseje i wiersze, i Józef Czapski opowiadający Prousta współwięźniom w Griazowcu - to dwa obrazy, które można by potraktować jako tekst emblematyczny, rodzaj schematu kulturowego. Odczytywane w porządku historyczno-biograficznym sa znakami indywidualnej sygnatury, niepowtarzalnej linii życia. W porządku symbolicznym mówią o nawykach i wzorcach kulturowych pokolenia przychodzącego na świat na przełomie XIX i XX wieku ${ }^{18}$. Odsyłaja jednak także do rozleglejszej koncepcji kultury opartej na kanonie sztuki, filozofii, nauk ścisłych, religii.

W tradycji anglosaskiej, tak bliskiej Miłoszowi, określa się ją jako klasyczną historię kulturowa, wskazując na ukształtowanie się „wielkiej tradycji” (termin zapożyczony z książki F.R. Leavisa wyznaczającej kanon literacki ${ }^{19}$ ) kultury między 1800 a 1950 rokiem $^{20}$. Powstanie w ciagu ostatnich dekad nowego paradygmatu i osadzenie pojęcia kultury przede wszystkim na gruncie studiów kulturowych doprowadziło do polaryzacji stanowisk wobec dorobku „okresu klasycznego”. Jednak nawet w szeregach krytyków uznających tę tradycję za anachroniczną i obarczających ją licznymi grzechami kultury „martwych, białych mężczyzn”, przede wszystkim elitaryzmem i konserwatyzmem, odżywa stale dialog z najbardziej znaczącymi jej reprezentantami, jak chociażby Matthew Arnoldem czy

${ }^{16}$ Cz. Miłosz, Ziemia Ulro, Warszawa 1982, s. 83.

${ }^{17}$ W liście do J. Błońskiego pisał: „Moje widzenie Historii? Nie wiem. Wiem tylko, że świat ludzki jest dla mnie niewypowiedzianie cudowny. Przez to, że oderwany od Natury, że sam się strukturalizuje jako artificiel'. Za: J. Błoński, Cz. Miłosz, dz. cyt., s. 58.

${ }^{18}$ Relacji Miłosz - Czapski poświęcił artykuł m.in. A. Fiut, Powinowactwa nie tylko z wyboru: Józef Czapski i Czesław Miłosz, [w:] Granit i tęcza. Dzieła i osobowość Józefa Czapskiego, red. A. Pilch, A. Włodarczyk, Kraków 2019.

${ }^{19}$ F.R. Leavis, The Great Tradition, London 1948.

${ }^{20}$ Por. P. Burke, Historia kulturowa. Wprowadzenie, przekł. J. Hunia, Kraków 2012, s. $8-25$. 
T.S. Eliotem ${ }^{21}$. To właśnie z Uwag ku definicji kultury Eliota wyprowadza się często, kwestionując wskazane tu podstawy jedności kultury europejskiej, nowe spojrzenie na pojęcie kultury rozumianej jako sposób bycia ${ }^{22}$. Miłosz, który był zafascynowany twórczością i osobą Eliota (tłumaczył jego teksty w czasie wojny, a tuż po niej udało mu się poznać go osobiście), nigdy nie miał sztywnych i ortodoksyjnych poglądów na temat tego, czym jest kultura. O otwartej i przenikliwej postawie Miłosza jako badacza kultury świadczy choćby prekursorski tom Kultura masowa gromadzacy przetłumaczone przez niego teksty. Książka opublikowana w 1958 roku miała, według intencji autora, zainicjować na gruncie polskim dyskusję nad kulturą masową ${ }^{23}$.

Refleksja Miłosza w wojennych esejach dotyczy zarówno pojęcia kultury, jak i kultury jako praxis w sensie „użycia” jej ze względu na przypisane jej wartości. Definicja kultury, jaką Miłosz formułuje pod wpływem doświadczeń wojennych, wyrasta z traktowania „kultury” jako pojęcia wartościującego a zarazem rozumianego jako przestrzeń absorbująca wartości. Domeną kultury w takim ujęciu staje się obszar nieświadomego sięgający w sferę mitu i rytuału. Równocześnie jednak Miłosz podkreśla jej wymiar formacyjny, celowościowy, hierarchiczny, umocowany w ratio. Jest ona przy tym modelowana w taki sposób, aby wyeksponować moment i konsekwencje kryzysu:

Żyjąc w porządku nagromadzonych przez prace pokoleń wartości - na które składa się wysiłek świętych, myślicieli, artystów - człowiek przebywa w pewnych ramach, jego myśli i uczucia rozwijaja się w pewien rytuał. Od słów pacierza, których uczy go matka, po lekturę i naukę w szkole, po doświadczenia społecznego życia czerpie ze skarbca humanistycznych hierarchii, nie wiedząc o tym, przyswaja wartościowanie, własne istnienie i istnienie ludzkości pojmuje jako walkę o coraz doskonalsze cele. Odczuwa, że człowiek jest nie tylko zwierzęciem, ale czymś większym. Jego zmysł moralny znajduje oparcie w obyczajach, w prawie, w przykazaniach religii, w obiegowym języku haseł i wezwań współobywateli. Moment rozdarcia tej kruchej powierzchni i zobaczenia dna ludzkiej natury jest dla niego momentem krytycznym. Wszystko wali się, wszystko wydaje się sztuczne i znikome w zestawieniu z elementarnymi faktami: okrucieństwo ludzi takie samo w skutkach jak okrucieństwo przyrody, łatwość, z jaką w jednej sekundzie czujące i myślące stworzenie zmienia się w martwy przedmiot [...] (s. 97-98).

Dla Miłosza piszącego te słowa w obliczu wojennego zniszczenia istotne stały się trzy stadia, przez które przechodzi człowiek. Stadium na poły

${ }^{21}$ Por. T. Eagleton, Po co nam kultura, przeł. A. Górny, Warszawa 2012; C. Jenks, Kultura, przeł. W. Burszta, Poznań 1999.

${ }^{22}$ Por. m.in. R. Williams, Culture and Society. Coleridge to Orwell, London 1958.

${ }^{23}$ Cz. Miłosz, Przedmowa, [w:] Kultura masowa, wybór, przekład, przedmowa Cz. Miłosz, komentarz J. Szacki, Kraków 2002.

125 Cóż po doświadczeniu wojny w czasie zarazy? 
nieuświadomionego wchodzenia i funkcjonowania w „ramach” pewnej kultury. Przeżycie wojenne jest „momentem krytycznym” konfrontacji kultury interioryzowanej z rzeczywistościa z gruntu obca, nie mieszczącą się doświadczeniowo, racjonalnie i emocjonalnie w horyzoncie wyznaczonym przez tak rozumianą kulturę. To przeżycie kruchości tkanki kultury i chwili jej rozdarcia zyskuje szczególną rangę, podlega intelektualnej refleksji i testowaniu w praktyce twórczej. Prowadzi do trzeciego i najważniejszego stadium, które rodzi pytanie: ,jak zachowa się człowiek nowoczesny wobec nieskończonego pejzażu ruin?" (s. 100). To pytanie dotyczy dwóch horyzontów czasowych: aktualnego, reakcję tu i teraz i tego dalszego wpisujacego się w przyszłość cywilizacji.

Te dwa portrety artystów i intelektualistów chciałabym zobaczyć w tej właśnie perspektywie zachowań i działań, w których konkretność doświadczanego zła uruchamia partykularne, ale i charakterystyczne gesty kulturowe. Chodzi zatem o reakcje zakorzenione w doświadczeniu traumy wojennej aktualizujące kompetencje kulturowe i odpowiadające zapotrzebowaniu na określony zespół wartości. Czynności mieszczące się w tradycyjnych aktywnościach kultury wysokiej: czytanie, pisanie, opowiadanie, dialog, empatia i partycypacja stały się wartościami ocalającymi. Obaj korzystają z metod uruchamiających wartości pozytywne, dających nadzieję, jak powiadał Miłosz, na znalezienie „prawdziwszego punktu oparcia” niż ten, który na ich oczach się rozsypywał.

Obrazy Miłosza i Czapskiego mają wiele cech zbieżnych, ale też pozwalają traktować się jako warianty. Punkt wyjścia jest ten sam: szukanie ratunku w świecie napawającym przerażeniem i budzacym rozpacz jest pierwszą instynktowną potrzeba. Myślenie i pisanie, uważność patrzenia ${ }^{24}$ i szukanie form artykulacji staja się praktykami ocalenia i podobne do „średniowiecznego rylca" $z$ legendy o Hieronimie są narzędziem oswojenia tego, co szalone i barbarzyńskie. Wiele lat później Miłosz wyzna:

Dlaczego napisałem wtedy książkę?... Z potrzeby ratowania się. Był to zabieg autoterapii, według następującego przepisu: jeżeli wszystko w tobie jest dygotem, nienawiścią i rozpacza, pisz zdania wyważone, doskonale spokojne; zmień się w stwór niecielesny, oglądający siebie cielesnego i bieżące wypadki z ogromnego dystansu. Nie podejmuję się orzekać, czy ten przepis może być stosowany zawsze, ale wtedy pomagał (s. 309).

Od „dygotu, nienawiści i rozpaczy” wypełniającego ciało i umysł do bezcielesnego dystansu pozwalającego na pisanie zdań „wyważonych i doskonale spokojnych” - to kierunek działania podpowiadany przez „instynkt

${ }^{24}$ Por. M. Popiel, Praktykowanie uważności i kultura ascezy. O Józefie Czapskim, „Pamiętnik Literacki” 2019, nr 4. 
kulturowy". Pisanie, które testuje świadomość, możliwości działania i skalę artykulacji, było dla autora Świata gestem autoterapeutycznym. Dla Miłosza i Czapskiego akt tworzenia: aktywność myśli, zdolność pióra w formułowaniu zdań w sytuacji „gry ze śmiercia”, miał sens egzystencjalny.

W obu przypadkach podejmowane praktyki kulturowe sa działaniami osadzonymi w silnych przesłankach etycznych określających skalę wyzwań, jakie rzuca czas wojny. Można przypuszczać, że już wtedy, w wojennych latach czterdziestych, bliska była im postawa, którą wyraźnie sformułował kilkadziesiąt lat później George Steiner w zbiorze esejów Zamek Sinobrodego. Kilka uwag $w$ kwestii przedefiniowania kultury. Dla Steinera, który zmarł w Cambridge 3 lutego 2020 roku, a zatem gdy Covid 19 zbliżał się do Wysp Brytyjskich, najważniejszym „sezonem w Piekle” pozostał Holocaust. W latach siedemdziesiątych w swoich wykładach ku czci Eliota ponawiał pytania wyrastające z doświadczeń wojennych, uznając je za ciagle żywotne dla współczesnej kultury:

Być może zwykłą głupotą, nieprzyzwoitością jest zastanawianie się nad definicją kultury w wieku pieców gazowych, gułagów, napalmu. [...] Musimy utrzymać w sobie ży wotne poczucie skandalu, tak obezwładniającego, że wpływa na każdy znaczacy aspekt naszej pozycji w historii i społeczeństwie. Musimy, jak powiedziałaby Emily Dickinson, utrzymać dusze w strasznym zaskoczeniu. [...] Nie ma nic naturalnego w naszym obecnym stanie. Nie ma żadnej oczywistej logiki czy godności w naszym przeświadczeniu, że „wszystko jest możliwe”. W rzeczywistości takie przeświadczenie deprawuje i obniża próg odczuwania odrazy [...]. Otępiałe marnotrawienie naszego obeznania z horrorem jest radykalną porażką człowieka ${ }^{25}$.

Postawa otępienia i marazmu będąca konsekwencja wojennej traumy wydaje się Steinerowi najgłębszą skazą na człowieczeństwie. Wielokrotnie uświadamiał ogromne ryzyko, jakim groziło pozostawanie w martwocie pourazowej bądź też poprzestawanie na trywialnym i powierzchownym ukojeniu. Przeżycie strachu i bólu zatopione w obezwładniającej chęci odrzucenia, wyparcia, wymazania może zostać „odkupione”. Impulsem do tego miało być stale podtrzymywane poczucie zaskoczenia, dziwności, prowokacji, absurdu.

W języku Miłosza można by tę jakość określić jako virtú umysłu. Terminem „virtú umysłu” ${ }^{26}$ posłużył się Miłosz w pośmiertnej charakterystyce

${ }^{25}$ G. Steiner, W zamku Sinobrodego. Kilka uwag $w$ kwestii przedefiniowania kultury, tłum. O. Kubińska, Gdańsk 1993, s. 57-58.

${ }^{26}$ Być może u źródeł tego terminu tkwi dawna tradycja estetyczna, która w czasach Miłosza ożywił m.in. Jacques Maritain, który w Sztuce i mqdrości pisał: „Sztuka należy do porządku intelektualnego, oddziaływanie jej polega na wyciśnięciu idei na materii: a więc mieści się w intelekcie artifexa [...]. Sztuka jest cnotą intelektu praktycznego [...]. (J. Maritain, Sztuka i madrość, przeł. K.K. Górscy, Warszawa 2001, s. 25-27). 
Gombrowicza. To dzielność umysłu, która często szła śladem dzielności ducha, myśl niezależna, która nie dawała się pochłonać morzu przeciwności. Ta postawa w ujęciu Miłosza odnosiła się do ruchu intelektu i pójścia pod prąd dominujących tendencji myślowych i ideowych, była „szukaniem ciepłej, fizycznie niemal uchwytnej prawdy ludzkiej czy ściślej, międzyludzkiej"27. Virtú umysłu w wojennym portrecie Miłosza i Czapskiego to splot woli i pragnienia, instynktu i intelektu człowieka kultury, „,człowieka Księgi”, który nie łudząc się, że potworności nada właściwy i pełny kształt, nazwę i sens, wierzy w ocalający rytuał wysiłku „działającego" umysłu. Aktywność intelektualna i tekstotwórcza/narracyjna Miłosza i Czapskiego jako gest kulturowy wydaje się być najważniejszym, choć nie nazwanym mitem wpisanym w Legendy nowoczesności. Tkwi w samej antropologicznej tkance „kulturowego doświadczenia cierpienia”. Ma także swój rodowód w formacyjnym i transformacyjnym wymiarze doświadczenia kulturowego, które stało się udziałem bohatera nowoczesności: artysty-obywatela. To także „refleksja uczestnicząca” wzmacniająca poczucie partycypacji w gwałtownej zmianie dokonujacej się w skali globalnej. W przedmowie do esejów (pisanej w grudniu 1944 roku) poddających krytyce fundamentalne mity nowoczesności zagadnienie aktu formacyjnego brzmi wyraźnie:

Gwałtowny skok historii i poczucie, że wiele jest do zrobienia, wywołują chęć pozbycia się dawnych nałogów i złudzeń. Ktokolwiek ma ambicję wzięcia czynnego udziału w przemianie, jako człowiek nowy i twórczy, musi starać się zaskakujące go zjawiska poznać i wytłumaczyć. Dziesięć razy, obciążony przestarzałymi metodami myślenia i stylu, będzie próbować daremnie. Za jedenastym uda mu się osiagnaćc, co zamierzał (s. 27).

Jaką cenę płaciło się wtedy, żeby dojrzeć do myśli, że „wiele jest do zrobienia”? Co trzeba było, żeby drżenie, nienawiść i rozpacz przekuć w potrzebę głębokiej refleksji nad przeformułowaniem kultury?

Zagadnienie relacji między gestem kulturowym i mitem zostaje podjęte na początku Legend nowoczesności. Pierwszy esej, Legenda wyspy, zaczyna się od opisu zapamiętanego obrazu - gestu kobiety podnoszącej ręce do skroni i wypowiadającej swoje pragnienie: „ach, znaleźć się na wyspie bezludnej, nie mieć z ludźmi nic do czynienia, uciec, uciec gdzieś daleko". Komentarz Miłosza wyjaśnia drogę od gestu do mitu:

Przypominając sobie ten obraz, myślę o wszystkich kobietach i mężczyznach, którzy podobnym gestem i podobnymi słowami wyrażali tęsknotę za zupełną samotnością. [...] Wyspa bezludna jest legenda i - jak każda legenda - mieści w sobie treść bogatszą niż zdarzenia, co ją zrodziły, co tworzą zewnętrzny szkielet dla jej rozwoju.

${ }^{27}$ Cz. Miłosz, Podzwonne, [w:] Zaczynajac od moich ulic, Paryż 1985, s. 313. 
Pewne przedmioty, dzięki ich „podziemnym” związkom z cechami natury ludzkiej, zyskują nad człowiekiem władzę niemal magiczna, wchodzą jako wyrazy do potocznego słownika, służąc do nazywania zatajonych pragnień (s. 29-30).

Otóż ten tok rozumowania chciałabym zastosować do dwójki bohaterów, Miłosza i Czapskiego, i pytać o gest uchwycenia pióra i dotknięcia nim kartki papieru, o gest sięgnięcia po powieść Tołstoja, o zamyślenie nad tym, czym jest kultura, o wysiłek uruchomienia pamięci przez Czapskiego, by - nie mając w ręce książki - postawić przed oczami współwięźniów obraz umierającego Prousta i Bergotte'a, o budowanie opowieści snutej półgłosem w drewnianej chacie w Griazowcu. W tych zdarzeniach zawiera się magia mitu „nazywającego zatajone pragnienia” człowieka Księgi, mitu kultury ocalającej, dającej pociechę, ożywiającej pasję myślenia, ocieplającej twarz drugiego człowieka, zachęcającej do otwartego spojrzenia w przeszłość i w przyszłość poza barbarzyństwo teraźniejszości. Ale ten mit, w przeciwieństwie do mitu wyspy, nie odnawia tęsknot eskapistycznych. Ogromu moralnego ryzyka, jakie niesie uległość wobec przyjemności estetycznej i „bezcielesnego” dystansu byli obaj doskonale świadomi.

Dwa rodzaje podejmowanych przez nich działań są wyborem z pewnego repertuaru praktyk kulturowych. Wariant Miłosza, czyli jego „przepis na życie”, zawiera się w lapidarnej formule nakazu: „pisz zdania wyważone, doskonale spokojne". Wkraczamy w aktywny, performatywny aspekt zachowania, który nie dotyczy kwestii składni i stylu czy gatunkowej konwencji literackiej, ale szerzej - zdystansowanego dyskursu porządkującego, którego harmonizujący rytm daje efekt kojący i regenerujący. Miłosz jako autor Legend nowoczesności wprowadza dwa wzorce: pierwszy jest osadzony w języku i kreacji świata charakterystycznego dla powieści realistycznej - Balzac i Tołstoj są tu kluczowymi postaciami, drugi - w myśleniu quasi-strukturalnym zaprzęgniętym do formułowania pytań na gruncie filozofii antropologicznej: jaka jest struktura przeżycia? jaka koncepcja człowieka jako twórcy i ofiary nowoczesnej mitologii? Miłosz używa zatem kultury po to, aby dokonać próby rekonstrukcji pewnych kulturowych struktur i systemów, z całą świadomością ograniczeń zmierza do całościowych narracji. Trud ich przeformułowania staje się rodzajem egzorcyzmu.

Wariant Czapskiego jako autora wykładów, które w druku zyskały tytuł Proust $w$ Griazowcu to przede wszystkim ten typ działań, które ocalająca funkcję wyprowadzają z empatycznych i wspólnotowych korzeni, sięgając po matrycę kultury oralnej. Narracja nie zmierza tu do rytmu całościowego, ale ma charakter eksplozywny, z linearnej tkanki literackiej wyrywa fragmenty: zdarzenia, przeżycia, emocje, sceny, słowa. 


\section{Jak „ogarnąć" Hiobową rzeczywistość? Hermeneutyka doświadczenia: struktury, matryce i mity kultury}

Rzeczywistość domaga się, żeby ją zamknąć w słowach, ale jest nie do zniesienia i jeżeli jej dotykamy, jeżeli jest tuż, nie wydobywa się z ust poety nawet skarga Hioba, wszelka sztuka okazuje się niczym w porównaniu z czynem. Natomiast ogarnąć rzeczywistość tak, żeby zachować ją w całym odwiecznym powikłaniu zła i dobra, rozpaczy i nadziei, można tylko dzięki dystansowi, tylko wznosząc się nad nią - ale to z kolei wydaje się moralna zdradą ${ }^{28}$.

Nieczyste sumienie poety będzie towarzyszyło Miłoszowi przez całe życie, jego echo odnajdziemy w licznych wierszach, wybrzmi mocno w tym fragmencie mowy Noblowskiej. A Miłosz - pisarz, eseista, intelektualista, badacz kultury? Gdy uruchomiony dystans wiedzy i filozoficznej refleksji przeniknie do dostępnej episteme, czy wtedy nie dochodzi do zdrady cierpiącego Hioba?

W Legendach nowoczesności centralne miejsce zajmuje tekst zatytułowany Przeżycie wojenne ${ }^{29}$. Tutaj koncentrują się najgłębsze i zarazem najbardziej newralgiczne dla zamysłu kompozycyjnego całego tomu problemy. Miłosz stawia w nim hipotezę o możliwości opisu „wewnętrznej struktury” przeżycia wojennego, tak jak można opisać przeżycie miłosne czy przeżycie okrucieństwa. Sam termin, jak i zamysł, odsyła do koncepcji „struktury przeżycia" Wilhelma Diltheya, która stała się później inspiracją m.in. dla koncepcji antropologii doświadczenia Victora Turnera ${ }^{30}$. Miłosz przekonuje, podobnie jak hermeneuta i antropolog, że doświadczenie wojenne ma charakter formacyjny i transformacyjny, a rozwijając się w czasie, ma strukture procesualna. Pisarz w ten sposób charakteryzuje własne jednostkowe doświadczenie a zarazem to będące udziałem wspólnoty: - „widzę wewnętrzna logikę i wewnętrzny rozwój mojego stosunku do rzeczywistości wojennej, co może nie jest tylko i wyłącznie moim udziałem" (s. 93). Ten modelowy wariant przeżycia wojny ma według Miłosza kilka składników zmieniających się sekwencjonalnie. Pierwszym jest odczucie chaosu, szaleństwa, stadnych reakcji, intensywnej emocjonalności. Drugi, choć obarczony rozpacza, jest zdecydowanie refleksyjny - dominuje w nim przeżycie utraty zaufania do cywilizacji. Kolejnym ogniwem jest włączenie w orbitę aktualnego doświad-

${ }^{28}$ Cz. Miłosz, Mowa noblowska, Królewska Akademia Szwedzka, grudzień 1980, [w:] tegoż, Zaczynajac..., s. 352 .

${ }^{29}$ Błoński w swoim Stowie wstepnym do Legend nowoczesności uzna go za jeden z najoryginalniejszych esejów Miłosza (tamże, s. 15).

${ }^{30}$ V. Turner, Dewey, Dilthey i gra społeczna: szkic z zakresu antropologii doświadczenia, [w:] Antropologia doświadczenia. Z epilogiem Clifforda Geertza, red. V.W. Turner, E.M. Bruner, przekład E. Klekot, A. Szurek, Kraków 2011. 
czenia przeszłości i przyszłości; refleksja nad przeszłością okazuje się sposobem pogłębienia zrozumienia przeżycia, a przyszłość - wprowadza wątek nadziei i ocalenia.

Miłosz postrzega przeszkody, jakie pojawiają się w procesie „dojrzewania" doświadczenia wojny do kategorii przeżycia kulturowego (brak języka i brak dystansu). Kilkakrotnie powraca do problemu ułomności form artykulacji doświadczenia dysponującego jedynie perspektywa „z centrum”.

Próba zrozumienia i opisania rzeczywistości wojennej z wnętrza tego czasu jest istotna decyzja Miłosza. Podejmuje to intelektualne wyzwanie wbrew przekonaniom Jerzego Andrzejewskiego, z którym prowadził wówczas ożywioną korespondencję, że „trzeba wyminąć swój czas, aby o swoim czasie pisać. Trzeba w pewnym sensie zdobyć się na nieczułość" (s. 174). Szczególne znaczenie ma wskazane przez Steinera zadanie oswojenia doświadczenia wojennego narzędziami dostępnymi rozumowi, uczuciom i językowi. Oznacza to przede wszystkim dokonanie swoistej translacji jednostkowego doświadczenia egzystencjalnego na doświadczenie kulturowe z obowiązującym wówczas przekonaniem o względnej odrębności obu ${ }^{31}$.

W pełni dostępne jest to pierwsze, jak sądzi Miłosz, będąc w samym środku czasu wojny niewiele możemy o nim powiedzieć, jesteśmy przede wszystkim skazani na analizę własnych przeżyć, „na odczytywanie samych siebie” (s. 93). Pozbawieni dystansu i „obiektywizujących” narzędzi ograniczamy się do daleko niedoskonałych sposobów ujęć: „O przeżyciach wojennych Europy będzie wiadomo dopiero wtedy, gdy staną się faktem społecznym, to znaczy wyładują się w nowych prądach filozoficznych i artystycznych, gdy utrwala się w walce z materiałem twórczym - w słowie, w bryle, w barwie, w dźwięku" (s. 93). Do istoty doświadczenia wojny można dotrzeć tylko przez przeżycie jednostkowe, które w dyskursywnie wyrażonej ocenie Miłosza ma zawsze podwójny status: jest źródłem wiedzy niepewnej i niepełnej, ale jednocześnie jedynym wiarygodnym. „O tym, jak ludzie przeżywają wewnętrznie tę wojnę $[. .$.$] wie się \mathrm{w}$ istocie bardzo mało. Jedynym niemal źródłem jest zastanawianie się nad własnymi przeżyciami” (s. 93). Jest świadom niedoskonałości instrumentów, jakie podsuwa jego pamięć kulturowa i własne możliwości tekstotwórcze i intelektualne. Szuka zatem matrycy kulturowej pomocnej w próbach ujęcia doświadczenia wojny. Dotyczy ona zarówno ram gatunkowych mocno eksponujących „ja”, jak i mimetycznych obrazów doświadczenia wojny w sztuce.

Chodzi zatem o trzy typy matryc kulturowych. Pierwsza to literatura intymistyczna, literatura doświadczenia wewnętrznego, która dostarcza

${ }^{31}$ Problematykę doświadczenia w kontekście dzieła Miłosza interpretował m.in. R. Nycz, Poeta XX wieku w poszukiwaniu formuły „,nowego doświadczenia”: przypadek Czestawa Mitosza, [w:] tegoż, dz. cyt., s. 261-290. 
ram narracyjno-kompozycyjnych esejom. Druga to klasyczna literatura realistyczna i psychologiczna, która mimetyczne reguły stosuje do analogicznych tematów wojny i charakterystycznych emocji (rodzaj krytyki tematycznej). Trzecia to strategia eseju filozoficzno-literackiego, która umożliwiając poruszanie się po obszarze literatury, zmierza do formułowania istotnych pytań dotyczących kondycji kultury.

Manifest, spowiedź dziecięcia wieku, pamiętnik intelektualny - takie propozycje konwencji literackich padaja w listach, esejach i przedmowie do Legendy nowoczesności, ale każda z nich budzi wątpliwości. Przywołania gatunkowe często tworzą ramy poetyki negatywnej. Miłosz zwierza się z potrzeby napisania „nowej «spowiedzi dziecięcia wieku», która swoją gwałtownością i bólem przewyższyłaby rachunki sumienia pozostawione przez tamtą romantyczną epokę" (s. 161). Przed realizacją tego projektu powstrzymuje go ryzyko nadużycia „krzyku i patosu”, wobec czego czuł zawsze awersję.

Poszukiwanie matryc kulturowych poprzez analogię tematyczną wiedzie go wprost do kanonicznych obrazów kultury europejskiej. Pisarz tłumaczy to najprościej: „Ale ponazywać części tego złożonego mechanizmu [przeżycia wojennego - przyp. M.P.] nie jest chyba rzeczą w tej chwili dostępna. Dlatego trzeba uciec się do pomocy pisarzy, którzy usiłowali ująć, jeżeli nie takie same, to przynajmniej podobne odczucia" (s. 94). Wojna i pokój Lwa Tołstoja i obrazy Francisco Goi zostają przywołane jako dwa najważniejsze „dokumenty wojny w kulturze europejskiej”. Znamienne, że docenia u Tołstoja przede wszystkim wnikliwość analizy i celność diagnozy, twierdząc, że „dzieje Pierre'a Bezuchowa w krytycznych dla Rosji dniach - stanowia studium przeżycia wojennego, godne pióra najtęższego filozofa" (s. 95). Charakterystyka zachowania Pierre'a Bezuchowa podczas pożaru Moskwy w 1812 roku podkreślająca „podniecenie graniczące z szaleństwem” naprowadza Miłosza na koncepcję pierwszej warstwy przeżycia wojennego: jest nim „stan rozbrojenia intelektualnego, „poczucie bezbronności intelektualnej” sprawiającej łatwość poddania się presji zachowań stadnych, przymusu działań pod dyktando tłumu.

Emocje, szalone pomysły bohatera Tołstoja tonace w chaosie i grze instynktów, maja, zdaniem Miłosza, zakorzenienie w świadomym poczuciu solidarności i pragnieniu złożenia ofiary. Dość łatwo przychodzi Miłoszowi przełożenie tej sytuacji na własne doświadczenia:

Ktokolwiek przypomni sobie jesień 1939 roku i miotanie się drobin ludzkich, z których jedne dazżły na wschód, a inne na zachód, gdy dla jednych znalezienie się w miejscu, skąd właśnie wyruszyły inne, było celem osiąganym drogą największych poświęceń - ten zgodzi się, że władać nimi musiały jakieś potężne siły, powstałe ze skrzyżowania się osobistych nawyków i skłonności z tak czy inaczej odczuwanym solidaryzmem [...] (s. 96). 
Ta reakcja, czyli pierwszy poziom przeżycia wojny osadzony w biologicznym wymiarze wspólnoty nie zaprząta nadmiernie uwagi pisarza. Prawdziwie dramatyczny poziom odsłania się wraz z raną zadana człowiekowi jako twórcy kultury. Twarz człowieka wyrzeźbiona przez formacyjne rytuały kultury zostaje najbardziej zraniona bestialstwem wojny. Słowa Tołstoja o Bezuchowie: „zamarła w nim wiara w celowość świata, w ludzkość, w swoją duszę, w Boga”, Miłosz tłumaczy jako „utratę wiary w cywilizację" (s. 97).

I tu wkracza mit jako instrument opisu owej utraty. Kolejne rozdziały Legend nowoczesności to historia „literackiej episteme" ${ }^{32}$ skonstruowana z, wydawałoby się przypadkowych, elementów. Od rozdziału o Danielu Defoe, „wymierzonym przeciwko wierze w przyrodzona dobroć poza cywilizacja”, poprzez eseje o Balzacu i demonicznym złu cywilizacji, o Stendhalu i Gidzie i ryzykownej drodze ku kultowi siły, o Wiliamie Jamesie i krytyce „godzenia się na fikcje i legendy jako normalny stan, poza który nie możemy wykroczyć", o Zdziechowskim i religii opartej na przyrodzonej potrzebie serca, aż po finałowy rozdział o „metafizycznej teorii sztuki” Witkacego.

$\mathrm{Z}$ jakiej potrzeby ducha Miłosz sięga po formę eseju i wciela się w historyka kultury? Autor Legend nowoczesności wkrótce po ich napisaniu miał świadomość podejrzanej niespójności tej książki. A jednak w 1944 roku powie wyraźnie, że „książka została zamierzona jako całość” (s. 27). Pragną bowiem Miłosz, zaczytując się dziełach Tołstoja i Balzaca, poczuć smak estetyki totalności. Napisać książkę, która z doświadczeń wojennych ogladanych przez pryzmat doświadczeń kulturowych stworzyłaby mikroepopeję wojenna. Cel tego przedsięwzięcia nie był jednak do końca ani estetyczny, ani hermeneutyczny.

\section{Podejrzana hermeneutyka nadziei}

Instrumenty poznania: struktury doświadczenia i matryce kultury sa potrzebne, powiada Miłosz wyjątkowo dobitnie w słowie poprzedzającym lekturę esejów wojennych, „,złowiekowi nowemu i twórczemu”, który „musi starać się zaskakujące go zjawiska poznać i wytłumaczyć”. Jest to modus vivendi tych ludzi kultury, których powinnością jest partycypacja, którzy „mają ambicję wziąć udział w przemianie” (s. 27). Chodzi zatem o performatywny akt „użycia kultury” w celach „ratowniczych”" ${ }^{33}$. Cała praca intelektu i słowa w opowieściach o mitach nowoczesności zmierzają do swoistego eg-

${ }^{32}$ Określenie Błońskiego: Słowo wstępne, [w:] Cz. Miłosz, Legendy nowoczesności..., s. 10.

${ }^{33}$ Taka perspektywa nawiązuje do jednego z podstawowych nurtów krytyki etycznej (por. m.in. W. Booth, The Company We Keep: An Ethics of Fiction, Berkeley 1988; M. Nussbaum, Love's Knowledge. Essays on Philosophy and Literature, Oxford 1990). 
zorcyzmowania szkodliwej iluzji, zwodniczej siły destrukcji, aby dać nadzieję, że człowiek „niszcząc legendy, które sam tworzy, znajdzie prawdziwy punkt oparcia" (s. 28).

W wersach poematu Świat pisanego być może w tym samym czasie, brzmi to tak:

Miłość to znaczy patrzeć na siebie,

Tak jak się patrzy na obce nam rzeczy...

A kto tak patrzy, choć sam nie wie,

Ze zmartwień różnych swoje serce leczy, [...]

Nie ten najlepiej służy, kto rozumie ${ }^{34}$

Konwencja prostoty przekazu, na jakiej zbudował Miłosz „poemat naiwny", ma swój kontekst w pewnym istotnym wątku esejów. Wyrażoną expressis verbis intencją autora było dokonanie „oczyszczenia” kultury po to, aby odsłonić dobro, dać nadzieję. Pytania o postawę religijną i jej zakorzenienie kulturowe pojawiają się nie tylko w eseju poświęconym Zdziechowskiemu, ale także w kontekście koncepcji altruizmu religijnego Tołstoja.

Pierre Bezuchow schodzi na sam padół nędzy w obozie jeńców - i właśnie tam, wśród zupełnego prymitywizmu, poniewierki i śmierci, zagarniającej kolejnych współwięźniów - przeżywa wielkie przeobrażenie, wychodzi stamtąd pogodzony ze światem i wewnętrznie wolny. Dokonuje się to poprzez dotknięcie do losu człowieka w całej jego prostocie, przemijalności i bólu. [...] odkrywa, że człowiek jest nie tylko zły, ale i prawdziwie dobry, że ziemia i życie są dobre, a zło nie powinno nam przesłaniać wielkiej i mądrej harmonii istnienia" (s. 101).

Nowe doświadczenie, które się wówczas rodzi, jest „trudne do nazwania”: „może nazywa się to po prostu miłością bliźniego” (s. 101).

Drugi kierunek ocalenia - religia - jest pozornie tylko podążaniem droga Tołstoja, bowiem zastrzeżenia, które czyni tu Miłosz, są znaczące. Przekonuje, że większą ocalającą moc ma europejski katolicyzm niż surowe i ascetyczne chrześcijaństwo wschodnie. Rzecz jednak nie w teologicznych różnicach, lecz kulturowej tradycji kształtującej mentalność i wyobrażenia Europejczyków:

[...] największe bestialstwo było w oczach katolika skutkiem przyrodzonego skażenia. Toteż człowiek, przedłużający tradycje zachodniego chrześcijaństwa, jest lepiej przygotowany do wyjścia z niewiary, w jaką wtrąca go podłość. Kryzys jest u niego mniej ostry, szybsze i sprawniejsze działanie antytoksyn. Pomimo dna, które odsłania się nieraz, upiera się, by mieć nadzieję, i ciagle oczekuje braterstwa ludzi - przez samo ujarzmienie dna i ujęcie w cugle biologicznych popędów (s. 103).

A zatem empatia, altruizm, poczucie braterstwa i katolickie tętno nadziei... Jak to brzmi naiwnie, jak ociera się o frazes i słabość intelektu! Miłosz

${ }^{34}$ Cz. Miłosz, Świat, poema naiwne, za: tegoż, Wiersze wszystkie..., s. 214-215. 
ubiega takie zarzuty w pełni świadom zasadności ich postawienia. W liście do Andrzejewskiego analizuje właśnie słabość kultury, chcąc jakby uchylić się przed pierwszym kamieniem, który przeciwnik może w niego rzucić.

Słabość. Nie mam zamiaru uchylać się, uciekać od zagadnienia słabości. Przeciwnie, urasta ono dzisiaj w zagadnienie pierwszej wagi. Cała „dobra” Europa, Europa tradycji humanistycznych, której dzieje pełne sa okrucieństw i zbrodni, ale przecie nigdy nie pochwalanych otwarcie - ta Europa okazała się śmieszna, bezsilna, niedołężna. „Zła” Europa, Europa otwarcie wielbionego bezprawia, narzuciła swoje zamiłowanie do efektów jaskrawych, narzędzi gwałtownych, idei ułatwionych, wziętych w monopol przez urzędy propagandy. Kogoś, kto przemawia jeszcze językiem dobrej Europy, ludzie słuchają z przyjemnościa, ale zarazem z niedowierzaniem. [...] Zgódźmy się, że brzmi to mdło, nijako, że wydaje się niemęskie i naznaczone hipokryzja. Ale w tej walce zła z prawem moralnym nie wynaleziono, jak dotychczas, wyrazów, które by potępiały czynienie krzywdy bliźniemu i brzmiały zarazem jak dźwięk trąb bojowych [...] (s. 169).

Porażką kultury, której smak Miłosz zaznał już w czasie wojny, a do której diagnozowania dojrzewał w ciagu kolejnych dekad, jest nie tylko „brak języka”, form artykulacji traumatycznych doświadczeń. Przy okazji lektury książki Michała Borwicza, ten szczególny gest kulturowy, jaki wykonało jego pokolenie, uświadomił sobie szczególnie wyraźnie: „Robili to zawsze w języku odziedziczonym, konwencjonalnym, właściwym temu środowisku kulturowemu, które ukształtowało ich przed wojna. Chcieli zostawić po sobie ślad w słowach, ale [...] język nie nadążał, jakby cofając się w gotowe toposy i formuły, czy nawet w nich szukając schronienia" ${ }^{35}$. Jednak już wtedy, w czasie wojny, dotkliwie odczuł jeszcze większą porażkę kultury: słabość dyskursu nadziei.

\section{Czapski i oczyszczający rytuał powrotów. Życiodajna sztuka albo grzeszna przyjemność}

Casus biografii i osobowości twórczej Czapskiego nie daje się wpisać w żaden z tradycyjnych modeli artysty. Pełen ostrych sprzeczności a równocześnie jakże spójny, z mocnymi uskokami i wewnętrznymi cezurami, a jednak z dominująca linią ciagłości. Tak łatwo dający się przekładać na sekwencje historii Polski i Europy XX wieku, aczkolwiek tak wyraziście unikatowy i paradoksalnie nieprzekładalny ${ }^{36}$. W tym jednym krótkim epi-

${ }^{35}$ Cz. Miłosz, Życie na wyspach, Kraków 1997, s. 14.

${ }^{36}$ Oprócz prac biograficznych poświęconych Czapskiemu, w tym przede wszystkim książki Erica Karpelesa, znakomitym portretem Czapskiego jest tom Czapski i krytycy. Antologia tekstów, w której, w kontekście biografii wojennej szczególnie cenny jest artykuł 
zodzie pobytu w obozie w Griazowcu trwającym od 18 czerwca 1940 roku do 2 września 1942 roku kondensuje się cały jego paradoks egzystencji.

W Griazowcu przestrzeń ogrodzona murem, zza którego przez pierwsze miesiące nie przedostawała się żadna wiadomość (zakaz korespondencji), ruiny siedemnastowiecznego klasztoru, a w nim pomieszczenie z drewnianymi pryczami i stołówka w refektarzu, obowiązkowy „czerwony kącik” z portretami Marksa, Lenina i Stalina zamiast ikon. Codzienność obozowa to praca i głód, lęk przed agresją strażników, niepewność jutra ${ }^{37}$. W tym obozowym świecie była jeszcze inna codzienność; jej świadectwami są zapisane skrawki papieru, kawałki gazet czy pudełek zapełnionych rysun$\mathrm{kami}^{38}$. O pisaniu i rysowaniu (czasem „podmalowywania” wyobrażonymi lub dziecinnymi farbkami) powie Czapski - „to był mój ratunek” (P. 93). Ta oczywistość terapeutycznej roli praktyk artystycznych była w refleksji Czapskiego rozpisana na wiele tonów i odcieni.

Ołówek był narzędziem pisarza i malarza, stawał się nim samym: „czułem podczas rysowania, czułem ten związek niezdarnego, niepewnego, zdeformowanego trochę rysunku, jakby między końcem mojego ołówka a mną nie było żadnej przerwy. Ja byłem na końcu ołówka" ${ }^{39}$. To utożsamienie jest

Marii Janion Artysta przemienienia. Zob. Czapski i krytycy. Antologia tekstów, wybór i oprac. M. Kitowska-Łysiak, M. Ujma, Lublin 1996.

${ }^{37}$ Gdy w kwietniu 2020 roku pandemia dotarła do Polski i skazała nas na wejście w „świat odwrócony”, Agnieszka Kosińska, kierowniczka Muzeum im. Emeryka Hutten-Czapskiego (w tym Pawilonu Czapskiego) w Krakowie, wysyłała e-mailem świąteczne życzenia wraz z obszernymi cytatami z pism Czapskiego z okresu wojennego z komentarzem: "Józef Czapski znalazł sposób na ten czas dojmującej ciszy, pytań i odpowiedzi”. Powołując się m.in. na fragment z Dziennika, twierdziła, że wtedy w Griazowcu, Czapski stworzył nowe „laboratorium formy życia”:

„Jak dobrze się przykryję kocami, to mi nie zimno, do niczego nie potrzebuję się spieszyć, żadna odpowiedzialność na mnie nie wisi, więc Griazowieckie warunki kontemplacyjne. Trzeba je użyć, wrócić do normy, wziąć się w ręce.

1 porządki w papierach

2 materiały w tekach

3 rysunek

4 angielski

5 listy [...]".

(Por. A. Kosińska: „Bywajcie zdrowi i naelektryzowani”! O korespondencji CzapscyHerbertowie. I nie tylko. „Konteksty. Polska Sztuka Ludowa” 2019, nr 4).

${ }^{38} \mathrm{~W}$ kwietniu 2020 roku w warszawskiej Kordegardzie miała być otwarta wystawa poświęcona artystom wywiezionym do sowieckich łagrów. Z powodu pandemii przeniesiono ją do Internetu (jest także dostępna na stronie: <jozefczapski.pl/czapski-ocalal-by-zachowac-o-nich-pamiec/>). Znalazły się na niej rysunki powstałe w obozach Starobielska, Kozielska, Pawliszczewa Boru, Griazowca, Komi i Peczory; ważne miejsce zajmują w ekspozycji rysunki Józefa Czapskiego.

39 J. Czapski, Wyrwane strony, red. B. Toruńczyk, przypisy M. Nowak-Rogoziński, „Zeszyty Literackie", Warszawa 2010, s. 99. 
miara myślowego, cielesnego i emocjonalnego zespolenia „ja” egzystencjalnego i ,ja” twórczego. Połączenia, które podobnie jak u Miłosza, było zawsze źródłem dramatycznych wewnętrznych napięć, ciągłego zadawania sobie i sztuce trudnych pytań. Problem legitymizacji sztuki w czasie wojny, gdy obrazy rozlewającego się okrucieństwa wytrącaja z ręki ołówek, powraca w najbardziej intymnych dialogach ze sobą samym:

Zawsze było dla mnie niepojęte, jak Leonardo i inni renesansowi artyści mogli tworzyć w okresie tortur, okrutnych zniszczeń, dżumy wytępiającej całe miasta. A teraz ja sam nie tylko słuchałem z upojeniem wierszy deklamowanych przez Parnickiego, ale czytałem z ostra satysfakcja perfumowane lekkie nowelki, „cacka” Halevy'ego, a ponure tło, wycie kobiety i wywożone trupy nie tłumiły głodu łatwej fikcji, który nawet nie był ucieczką przed rzeczywistością dla mnie, ale formą stępienia wobec otaczającej rzeczywistości ${ }^{40}$.

Dla Czapskiego codzienna czynność pisania i rysowania nie staje się rutyna traktowana jak porcja lekarstwa. Przypomina raczej rytuał przemienienia z jego „źródłem życiodajnym”:

Udało mi się nawet dostać guziczki farb dziecinnych, i po parę tygodni z rzędu drobną plamką akwarelowa ,portretowałem” kolegów czy malowałem martwą [...]. I na zawsze mnie ten okres przekonał, że najsuchszy, bez śladu „muzyki”, najmizerniejszy niewolniczy w stosunku do natury rysunek, ale rysunek codziennie pogłębiany, uściślany do skraju swych możliwości, jest dla mnie, a uparcie mi się zdaje, że i dla każdego malarza, źródłem życiodajnym ${ }^{41}$.

Warunkiem dotarcia do owego „źródła życiodajnego” było zbliżenie się do postrzeganej rzeczywistości: żywiołem tego artysty była mimesis. Rzeczywistość jako materia rysunku (portrety kolegów współwięźniów czy banalne przedmioty, jak miska do mycia) wydaje się być uchwytna w chwilach koncentracji uwagi i zintensyfikowania percepcji zmysłowej.

Philippe Lacoue-Labarthe zarysował w swoim studium o Poezji jako doświadczeniu, podążając za myślą i tekstami Celana, mocną opozycję między sztuką mimetyczną a poezją. Poezji jako doświadczeniu przeciwstawia „życie w mimesis”.

Życie w sztuce lub w świetle sztuki, życie spędzone na zajmowaniu się sztuką - czy jeszcze prościej: życie przeniknięte sztuka, przez nią realizowane, coś, co nazwałbym życiem w mimesis (w reprezentacji) to życie pod znakiem „zapomnienia o sobie" [...] mówienie, zezwalanie, by język nas uwodził i unosił, dowierzanie mu, czy może nawet czerpanie z niego lub podporządkowywanie się mu, to tkwienie $\mathrm{w}$ „zapomnieniu o sobie" [...]. Język nie jest Unheimliche, aczkolwiek tylko on właśnie zawiera w sobie ewentualność Unheimliche. Jednak Unheimliche pojawia się czy

${ }^{40}$ J. Czapski, Na nieludzkiej ziemi, Warszawa 1990, s. 150-151.
${ }^{41}$ J. Czapski, Tło rosyjskie, [w:] tegoż, Patrzac..., s. 91-92.

137 Cóż po doświadczeniu wojny w czasie zarazy? 
raczej ustanawia i coś w człowieku zmienia. Przemieszcza istotę ludzka, coś w niej wywraca czy zmienia, wyrzucając ją z tego, co ludzkie - wraz z pewną postawa zarysowaną w języku: postawą ,artystyczna, czy jak kto woli, mimetyczną". [...] Nasuwa się więc myśl, że motyw zapomnienia i odwrócenia, a tym jest Unheimliche, to w perspektywie językowej katastrofa istoty ludzkiej. I to właśnie tłumaczy, że poezja [...] okazuje się każdorazowo zakłóceniem języka. [...] I tym właśnie jest poezja: przerywaniem języka, zawieszaniem toku mówienia, wprowadzaniem cezury: to „rwany oddech i słowa” ${ }^{42}$.

Tak rozumiana poezja jest słowem „poświadczającym «obecność istoty ludzkiej»” w jej zawieszeniu języka, wstrzymaniu oddechu, spazmie. Cały nurt poezji „oniemiałej” po doświadczeniach wojny i Holocaustu sygnowany nazwiskami właśnie Celana czy chociażby Różewicza, lokuje się na antypodach postawy, jaką reprezentują Czapski i Miłosz.

Czapski, świadek epoki sowieckich obozów, którego „życie przeniknięte było sztuka”, wyrównywał oddech, gdy brał do ręki ołówek: „znowu widzę, oddycham oczami" ${ }^{43}$ - to zdanie zapisane w późniejszych notatkach oddaje przeżycia z czasów obozowych. Poddawał się chwili, w której mógł wzrokiem podążać za modelem i pozostawiać na kawałkach kartek, „ślad najwyższego skupienia, przejścia poza rzeczywistość poprzez wpatrzenie się w jej okruch" ${ }^{4}$. W Griazowcu to nie były obrazy, ale rysunki-notatki, które nigdy nie miały spełnić swojej głównej funkcji bycia przygotowaniem do obrazu, znikały bowiem wraz z kolejną rewizją przeprowadzaną przez strażników obozu. Ale to w nich tkwiła „siła doznania”, „chwila widzenia”45. Wyobraźnia twórcy działała także wtedy, gdy patrzył przez okno szpitala wojskowego i „myślał nad tym, jak wydobyć ten dźwięk niebieskości, ten krzyk białej ramy okiennej na niebieskim niebie"46. I także wtedy, gdy:

Przez błogosławioną szparę nad zabitym oknem dojrzałem wówczas jakąś cerkiew z wysoką dzwonnicą: mieszanina renesansu i wschodu w rysunku okna, smukłych kolumn, drobnych złotych kopułek. Po roku drutów urzekła mnie ta lekka koronka architektury w niebieskiej cichości księżycowej poświaty ${ }^{47}$.

Wtedy także, gdy siedząc w celi w Griazowcu, ożywiał w pamięci swoje własne namalowane przed wojną obrazy, by stworzyć ich miniaturowa

${ }^{42}$ P. Lacoue-Labarth, Poezja jako doświadczenie, przekład J. Margański, Gdańsk 2004, s. 63.

${ }^{43}$ J. Czapski, Wyrwane strony..., s. 125.

${ }^{44}$ J. Pollakówna, Olśnienia i medytacje - o malarstwie Józefa Czapskiego, [w:] Czapski $i$ krytycy..., s. 163.

${ }^{45}$ J. Pollakówna, „Ja bytem na końcu ołówka”, [w:] Czapski i krytycy..., s. 80-81.

${ }^{46}$ J. Pollakówna, Olśnienia i medytacje, [w:] Czapski i krytycy..., s. 163.

${ }^{47}$ Cyt. za: J. Zieliński, Józef Czapski. Krótki przewodnik po dtugim życiu, Warszawa 1997, s. 70. 
kolekcję na skrawkach papieru. Ta sporządzona w obozie galeria zaginęła podobnie jak większość oryginałów.

Ten gest ręki chwytającej za ołówek nie był ekspresją rozpaczy, krzykiem ,z otchłani” błagającym los o ocalenie, był raczej, jak powie sam Czapski, każdorazowo „doprowadzaniem przeżycia do świadomości” ${ }^{3}$, był formą wewnętrznej rozmowy ze światem prowadzonej w najgłębszym osamotnieniu. Wątek kontemplacji i metafizycznego wymiaru przeżycia estetycznego pojawia się, z inspiracji samego Czapskiego, wielokrotnie w komentarzach interpretatorów jego malarstwa. W odniesieniu jednak do doświadczeń obozowych lat czterdziestych wydaje się, że inny trop jest tutaj ważniejszy:

„Człowiek maluje procent od kontemplacji” - pisze Norwid, ale człowiek żyje także procent od kontemplacji, kiedy ginie ten moment oddechu, samotnego spojrzenia, obcowania bezinteresownego, przychodzi nie tylko obojętność, ale nienawiść życia ${ }^{49}$.

Doświadczenie estetyczne, które jest integralnym składnikiem przeżycia wojny ma dominujacy wymiar etyczny i aksjologiczny. Waloryzowanie rzeczywistości, która jawi się poprzez nieusuwalne doznanie bólu, strachu, niepewności i osamotnienia zmierza do pytania o „nienawiść życia” a zarazem o doznania pozytywne, takie jak szczęście i empatia. Czapski, podobnie jak Miłosz, podejmuje często problem „niemoralności sztuki”. Obaj, choć pełni wątpliwości, są po stronie sztuki, która stając twarzą w twarz ze złem świata, do końca szuka oparcia w cudowności i niesamowitości stworzenia i „dajmonicznego" stwarzania.

Gustaw Herling pisał w notatce Dziennika z 1985 roku, że chciałby, „aby kiedyś czytano Inny świat jako Bildungsroman z odległej i zamkniętej epoki sowieckiej cywilizacji więziennej" ${ }^{\circ}$. Z pewnością tak też można czytać Dzienniki i $Z$ nieludzkiej ziemi Czapskiego, dodatkowo wzbogacone o wątki Kunstlerroman.

Na stronach Dzienników, w narracji wspomnieniowej dotyczącej czasów wojny, słowo „szczęście” pojawia się kilkakrotnie ${ }^{51}$. To uczucie bywa częścią codziennej obozowej udręki, pobyt w szpitalu jako moment jej przerwania, wydaje się Czapskiemu czasem szczęśliwym. Za każdym razem jednak odczuwa niestosowność tego słowa (,brzmi to dość dziwnie, ale muszę przyznać,

${ }^{48}$ J. Czapski, Dzienniki, cyt. za: J. Pollakówna, „Ja bytem na końcu ołówka”, [w:] Czapski i krytycy..., s. 80 .

${ }^{49}$ Cyt. za: J. Zieliński, dz. cyt., s. 47.

${ }^{50}$ G. Herling-Grudziński, Dziennik pisany noca 1984-1988, Warszawa 1996, s. 130.

${ }^{51}$ O szczęściu jako jednym z intrygujących motywów Dżumy Camusa, wspomina Czapski w recenzji napisanej tuż po ukazaniu się powieści w 1947 roku (,La peste”, [w:] J. Czapski, Czytajac, wybrał, opracował i wstępem poprzedził J. Zieliński, Kraków 2015, s. 68-72). Pojęciu „szczęścia” w poglądach Czapskiego poświęcił kilka stron Jan Zieliński w artykule Czapski: trzy przekroje, [w:] tegoż, dz. cyt., s. 62-67. 
że trzy, cztery tygodnie spędzone w szpitalu zaliczam do prawie szczęśliwych" ${ }^{2}$ ). Zadaje wówczas pytania, które w narracjach wojennej traumy pojawiają się rzadko:

Czy jest takie miejsce, taka gehenna, gdzie by człowiek uwolniony od fizycznego cierpienia, głodu, bólu i chłodu czy nawet tylko gorączkowej, ściganej odpowiedzialnościa pracy nie był zdolny przeżyć kwadrans szczęścia?53

Ten dwuznaczny stan szczęścia zostaje wywołany przede wszystkim przez najbardziej podejrzane medium, czyli literaturę. Chwile zanurzenia się w świecie powieści Prousta: były to ,godziny naprawdę miłe wbrew wszystkim ciosom i przyszłości najbardziej niepewnej - były szczęśliwe” ${ }^{4}$.

\section{Proust w Griazowcu, czyli Anty-Szeherezada}

Książka jako atrybut więźnia pojawia się na licznych portretach rysowanych przez Czapskiego w sowieckich obozach. Czytanie stanowiło rodzaj wspólnotowego rytuału:

Pamiętam lekturę książki Balzaca Kobieta trzydziestoletnia w tłumaczeniu Boya. Książka była cała rozdarta na oddzielne strony, wypożyczano ją nam na bardzo krótko, czytaliśmy ją w pięciu naraz, każdy z nas poganiał drugiego, by szybciej dostać stronę następna. Z całej książki, w której zresztą brakowało sporo stron, zostało mi jedynie wspomnienie męczącego pośpiechu ${ }^{55}$.

Ilu jeńców w rzeczywistości było zagorzałymi czytelnikami prozy francuskiej i rosyjskiej nie wiadomo, ale liczbę słuchaczy odczytów Czapskiego o Prouście autor określił na około czterdziestu na trzystu oficerów polskich ulokowanych w obozie. Opisał szczegółowo okoliczności, w których odbywały się prelekcje:

Koledzy siedzieli na waskich i chwiejnych ławkach, słuchali w półmroku izby o przygodach księżnej Guermentes, o śmierci Bergotte’a, o mękach zazdrości Swanna. Potem w wielkim refektarzu klasztornym - naszej stołówce (cuchnęło tam zwykle brudnymi statkami i kapusta) - dyktowałem część tych odczytów najlepszym kolegom [Joachimowi Kohnowi i Wiesławowi Cichemu - przyp. M.P.], którym strony te poświęcam (P, s. 97).

Czym była ta opowieść o Prouście (,moim Prouście”, jak powiadał) i jego bohaterach, jaką Czapski snuł w obozie jenieckim w Griazowcu, nie w po-

\footnotetext{
${ }^{52}$ J. Czapski, Wspomnienia starobielskie, cyt. za J. Zieliński, dz. cyt., s. 63.

${ }^{53}$ J. Czapski, Tło rosyjskie, [w:] tegoż, Patrzac..., s. 97.

${ }^{54}$ Tamże.

${ }^{55}$ J. Czapski, Wspomnienia starobielskie, Rzym 1945, s. 37.
} 
rządku biografii czy historii, ale w porządku kultury? Czym było to zdarzenie z dziejów wojennej gehenny wyreżyserowane według reguł dziwnego performansu? Było na pewno częścią wielkiego mitu kultury posiadającej moc ocalenia. Ciagnąca się opowieść, jak w historii Szeherezady, miała cechy jeszcze jednej gry ze śmiercią. Terapeutyczna rola opowieści przywracajacej do życia różniła się od sytuacji z Baśni tysiqca $i$ jednej nocy pod jednym względem. W arabskiej narracji napięcie między opowieścią a śmiercią ma jeden cel - ocalenie życia narratora. W tym dziwnym wojennym performansie rozgrywającym się wobec „potwora bez twarzy” stawką jest życie wspólnoty, wszystkich uczestników: opowiadającego i słuchaczy. Reżyser tworzy scenę spektaklu, w którym wspomnienie lektury tekstu Prousta pobudza empatię łączącą opowiadacza i słuchających. Uwznioślający gest opowieści służy rytuałowi powrotu do świata z jego zmysłową różnorodnością i życia z jego naturalnymi emocjami i doświadczeniami.

Michel Foucault w swoim klasycznym tekście Kim jest autor? zaadaptował sytuację Szeherezady do współczesnej problematyki praktyk pisania i mówienia ${ }^{56}$. Jednym z ważnych tematów przewijających się w historii kultury jest ,powinowactwo pisania i śmierci”; zdaniem Foucaulta nowoczesna literatura realizująca zasadę anihilacji autora przeciwstawia się dawnej tradycji sięgającej czasów greckiej epopei:

Jeśli bohater decydował się młodo ginąc to tylko dlatego, że jego życie, uświęcone i wyolbrzymione dzięki śmierci przechodziło do nieśmiertelności. Zapłatą za akceptację śmierci była opowieść. Także literatura arabska - myślę oczywiście o „Baśniach tysiąca i jednej nocy" - za swój pretekst obierała opór wobec śmierci: tylko dlatego opowiadano do białego świtu, by uniknać śmierci, by opóźnić moment, w którym usta narratora zamilkna na zawsze. Opowieść Szeherezady jest rozpaczliwym przenicowaniem zbrodni, niezmordowanym wysiłkiem wykluczenia śmierci poza krąg istnienia ${ }^{57}$.

Po czym konkluduje: „nasza kultura nadała nowy kształt próbom zwalczenia śmierci poprzez opowieść" - zabijając autora w doskonałym spektaklu „obojętności”. Jednym z kluczowych przykładów dzieła, które zamiast

${ }^{56}$ Foucault rozwijając swoją tezę o zniknięciu autora w literaturze nowoczesnej, przywołuje rozważania św. Hieronima zamieszczone w De viris illustribus. Święty tłumacz Biblii próbuje rozstrzygnąc problematyczną kwestię tożsamości autora kilku dzieł, wskazując cztery kryteria, które Foucault zamienia na cztery modalności określające współcześnie funkcję autora. Proust w Griazowcu winien być zapewne sygnowany przez Czapskiego czytającego powieść w Paryżu, Czapskiego „odzyskującego” pamięć W poszukiwaniu straconego czasu w Rosji, sporządzającego notatki, wygłaszającego wykłady, dyktującego tekst i w końcu przygotowującego go do druku. A do tego dochodzą inni ,autorzy” - ci, którzy pisali pod dyktando, a także ci, którzy rękopisy (zaginione) przepisali na maszynie...

${ }^{57}$ M. Foucault, Kim jest autor?, [w:] tegoż, Powiedziane, napisane. Szaleństwo i literatura, wybrał i opracował T. Komendant, posłowie M.P. Markowski, Warszawa 1999, s. 201. 
zapewnić autorowi nieśmiertelność - zabija go, jest według Foucaulta $W$ poszukiwaniu straconego czasu Prousta ${ }^{58}$. Przypadek Czapskiego - czytelnika, także pod tym względem jest odmienny - życie Prousta jest tu skutecznym kluczem do lektury jego dzieła. Czapski jest nie tylko zafascynowany światem bohaterów kreowanych przez Prousta, ale z wyraźną empatią traktuje postać autora. Żywe osobiste emocje budzą w nim uczucia, które przypisuje pisarzowi, a które odnajduje także w przeżyciach fikcyjnych postaci: namiętność, zazdrość, tkliwość, czułość, współczucie. Jednak najbardziej przyciaga Czapskiego do Prousta wyobrażone doświadczenie fizycznego bólu towarzyszącego twórczej pasji: cierpienie chorego, samotnego artysty zamkniętego w szczelnie izolowanym, ciasnym i zaniedbanym mieszkaniu ${ }^{59}$. Proust Czapskiego jest więźniem Griazowca, codziennie wykonuje tę samą pracę: bierze do ręki ołówek lub gromadzi wokół siebie słuchaczy, aby rozpocząć swoją opowieść. I nie jest to „niezmordowany wysiłek wykluczenia śmierci poza krag istnienia”, to przede wszystkim wysiłek powstrzymania nienawiści do świata i trud kuszenia do życia.

$$
* * *
$$

Powracaliśmy w czasie pandemii do najprostszych gestów empatii i aprobaty: śpiewów, muzyki, oklasków, nie tylko dlatego, że podpowiadała nam to popkultura czy stylistyka mediów społecznościowych, powróciliśmy do oglądania dobrze znanych filmów i czytania przeczytanych już powieści, nie tylko dlatego, że nie było nowych albo były trudniej dostępne. Może także dlatego, że w tym „odwróconym świecie” XXI wieku szukaliśmy sposobów na oswojenie szerzącego się strachu i cierpienia poprzez kulturowe gesty przywracające do łask prostotę, naiwności form, odkrywające wartość powtórzenia. Gestów rodzących się z przyzwolenia na tęsknotę za spokojnymi, rytmicznymi zdaniami, długimi opowieściami, wyrazistą fabuła, utopijnym światem dialektycznego, a więc przewidywalnego porządku, który może rozciaga się aż po horyzont nadziei ${ }^{60}$.

${ }^{58}$ Tamże, s. 202.

${ }^{59}$ Por. A. Jarmuszkiewicz, Tropy Prousta. Problem recepcji literackiej w literaturze polskiej po 1945 roku, Kraków 2019. Autorka przedstawia interpretację Czapskiego z perspektywy „reprezentacji pamięci afektywnej” (s. 213-222).

${ }^{60}$ Kwietniowy numer „Książek”, który ukazał się na początku pandemii w Polsce, zawiera propozycję kanonu „25 arcydzieł, które leczą strach”. Juliusz Kurkiewicz poprzedza cykl 25 interpretacji uwaga: „Tak jak nad wynalezieniem szczepionki, trwa również gorączkowa praca nad nowymi rozwiązaniami dla świata. W czasach nowej powagi przestaliśmy się wstydzić śmieszności. Nie wstydzimy się pytań zarezerwowanych przez wieki dla dzieł pisarzy i myślicieli”. Pierwszym utworem na liście lektur „kanonicznych” są Lata nauki Wilhelma Meistra J.W. Goethego; rekomenduje tę książkę Maria Janion, kończąc swój tekst 
Jak brzmiałyby dziś Legendy ponowoczesności? Jak Miłosz rozpocząłby opisywanie doświadczenia pandemii zamknięty w 2020 roku w nowojorskim mieszkaniu? Czy Czapski uwięziony na wycieczkowym statku-widmie z zarażonymi na Covid 19 opowiadałby nadal $W$ poszukiwaniu straconego czasu?

Konkludując, zmierzam do postawienia szeregu pytań, z których pierwsze byłoby parafrazą słów Miłosza z Przedmowy do tomu Ocalenie: Czym jest kultura, która nie ocala narodów ani ludzi? Czy doświadczenie globalnej pandemii zasługuje na refleksję nad przeformułowaniem kultury? ${ }^{61}$ Czy w momencie, gdy współcześni socjologowie przekonali już samych siebie do tego, że „kultura ma znaczenie” 62 , czy wierzą w to jeszcze humaniści? Czy projekt „kultury ratowniczej” inspirowany „historia ratownicza” ${ }^{63}$ jest dziś w zasięgu naszych możliwości? Czy wizja kultury, która ukształtowała Czesława Miłosza i Józefa Czapskiego i towarzyszyła im w czasie wojny jest dziś tak anachroniczna, że można do niej wracać jedynie z historycznego dystansu? Czy w imię mądrości praktycznej, arystotelesowskiej phronesis, podzielimy zdanie wypowiadane niekiedy przez historyków kultury, iż „kultura, nawet jeśli nie odróżnia rzeczy dobrych od złych, zachowuje moralną siłę, autorytet estetyczny i praktyczną użyteczność; potrzebuje jedynie trochę więcej pielęgnacji [...]”64.

\section{BIBLIOGRAFIA}

Antropologia doświadczenia. Z epilogiem Clifforda Geertza, red. V.W. Turner, E.M. Bruner, przekład E. Klekot, A. Szurek, Kraków 2011.

Bloom H., Zachodni kanon. Ksiażki i szkoła wieków, przekład B. Baran i M. Szczubiałka, Warszawa 2019.

Błoński J., Miłosz C., Listy 1958-1997, zebrał, przepisał i opatrzył przypisami A. Puchejda, Gdańsk 2019.

przesłaniem: „Dzisiejsza edukacja poprzez literaturę i sztukę powinna być wskazywaniem bogactwa, jakim jest osobowość zdolna świadomie odwrócić się od chciwości i żądzy władzy”. (M. Janion, Do czego dażyć? , „Książki. Magazyn do czytania” 2020, nr 2, s. 16).

${ }^{61}$ Inspiracją do tych rozważań mogłaby być uwaga Susan Sontag wypowiedziana w 1996 roku w posłowiu do powstałego w latach sześćdziesiąych tomu esejów Przeciw interpretacji: „Świat, w którym powstały te eseje, przeminą. Dziś nie żyjemy już w poczuciu utopii. Obecne czasy wydaja nam się epoką końca - czy, ściśle rzecz biorąc, tuż po końcu wszystkich ideałów, a zatem także kultury, niemożliwa jest bowiem prawdziwa kultura bez altruizmu" (S. Sontag, Przeciw interpretacji i inne eseje, przełożyli M. Pasicka, A. Skucińska, D. Żukowski, Kraków 2018, s. 416).

${ }^{62}$ Por. Kultura ma znaczenie. Jak wartości wptywaja na rozwój społeczeństw, red.

L.E. Harrison, S.P. Huntington, przeł. S. Dymczyk, Poznań 2003.

${ }^{63}$ E. Domańska, Historia ratownicza, „Teksty Drugie” 2014, z. 5.

${ }^{64}$ F. Inglis, Kultura, przekład M. Stolarska, Warszawa 2007, s. 171.

143 Cóż po doświadczeniu wojny w czasie zarazy? 
Booth W., The Company We Keep: An Ethics of Fiction, Berkeley 1988.

Burke P., Historia kulturowa. Wprowadzenie, przekł. J. Hunia, Kraków 2012.

Choynowski P., Herbert i jego ttumacz, „Postscriptum Polonistyczne” 2012, nr 1.

Czapski i krytycy. Antologia tekstów, wybór i oprac. M. Kitowska-Łysiak, M. Ujma, Lublin 1996.

Czapski J., Czytajac, wybrał, opracował i wstępem poprzedził J. Zieliński, Kraków 2015.

Czapski J., Na nieludzkiej ziemi, Warszawa 1990.

Czapski J., Patrzqc, wybór, przedmowa i posłowie J. Pollakówna, Kraków 2016.

Czapski J., Wspomnienia starobielskie, Rzym 1945.

Czapski J., Wyrwane strony, red. B. Toruńczyk, przypisy M. Nowak-Rogoziński, „Zeszyty Literackie", Warszawa 2010.

Domańska E., Historia egzystencjalna, Warszawa 2012.

Domańska E., Historia ratownicza, „Teksty Drugie” 2014, z. 5.

Droit R.-P.. Wielkie doświadczenie, przeł. R. Ryziński, „Teksty Drugie” 2006, z. 3.

Eagleton T., Po co nam kultura, przełożył A. Górny, Warszawa 2012.

Eliot T.S., Uwagi ku definicji kultury, przekład J. Rybski, Kraków 2016.

Foucault M., Kim jest autor?, [w:] tegoż, Powiedziane, napisane. Szaleństwo i literatura, wybrał i opracował T. Komendant, posłowie M.P. Markowski, Warszawa 1999.

Franaszek A., Miłosz. Biografia, Kraków 2012.

Granit i tęcza. Dzieła i osobowość Józefa Czapskiego, red. A. Pilch, A. Włodarczyk, Kraków 2019.

Herling-Grudziński G., Dziennik pisany noca 1984-1988, Warszawa 1996.

Inglis F., Kultura, przekład M. Stolarska, Warszawa 2007.

Janion M., Do czego dażyć?, „Książki. Magazyn do czytania” 2020, nr 2.

Jarmuszkiewicz A., Tropy Prousta. Problem recepcji literackiej w literaturze polskiej po 1945 roku, Kraków 2019.

Jenks C., Kultura, przeł. W. Burszta, Poznań 1999.

Karpeles E., Prawie nic. Józef Czapski. Biografia malarza, przełożył M. Fedyszak, Warszawa 2018.

Kowalczyk A.S., Kryzys świadomości europejskiej w eseistyce polskiej lat 1945-1977 (Vincenz - Stempowski-Miłosz), Warszawa 1990.

Kudyba W., Święty Hieronim i Pan Cogito, <https://herbertguru.wordpress. com/2014/10/20/wojciech-kudyba-swiety-hieronim-pan-cogito/> [dostęp: 10.01.2021].

Kultura ma znaczenie. Jak wartości wptywaja na rozwój społeczeństw, red. L.E. Harrison, S.P. Huntington, przeł. S. Dymczyk, Poznań 2003.

Kultura masowa, wybór, przekład, przedmowa C. Miłosz, komentarz J. Szacki, Kraków 2002.

Lacoue-Labarth P., Poezja jako doświadczenie, przekład J. Margański, Gdańsk 2004.

Leavis F.R., The Great Tradition, London 1948.

Maritain J., Sztuka i madrość, przeł. K.K. Górscy, Warszawa 2001.

Miłosz Cz., Legendy nowoczesności, Kraków 2009.

Miłosz Cz., Metafizyczna pauza, Kraków 1995.

Miłosz Cz., Rodzinna Europa, Kraków 1994.

Miłosz Cz., Wiersze wszystkie, Kraków 2018.

Miłosz Cz., Zaczynajac od moich ulic, Paryż 1985. 
Miłosz Cz., Ziemia Ulro, Warszawa 1982.

Miłosz Cz., Życie na wyspach, Kraków 1997.

Nussbaum M., Love's Knowledge. Essays on Philosophy and Literature, Oxford 1990.

Nycz R., Poetyka doświadczenia. Teoria - nowoczesność - literatura, Warszawa 2012.

Popiel M., Praktykowanie uważności i kultura ascezy. O Józefie Czapskim, „Pamiętnik Literacki” 2019, nr 4.

Sieroń-Galusek D., Moment osobisty. Stempowski, Czapski, Miłosz, Katowice 2013.

Sontag S., Przeciw interpretacji i inne eseje, przeł. M. Pasicka, A. Skucińska, D. Żukowski, Kraków 2018.

Steiner G., W zamku Sinobrodego. Kilka uwag w kwestii przedefiniowania kultury, tłum. O. Kubińska, Gdańsk 1993.

Tischner Ł., Sekrety manichejskich trucizn. Miłosz wobec zła, Kraków 2001.

Williams R., Culture and Society. Coleridge to Orwell, London 1958.

Zieliński J., Józef Czapski. Krótki przewodnik po dtugim życiu, Warszawa 1997. 
